\title{
Questioning the Role of the Indian Administrative Service in National Integration
}

Dalal Benbabaali

\section{OpenEdition}

\section{Journals}

Electronic version

URL: https://journals.openedition.org/samaj/633

DOI: 10.4000/samaj.633

ISSN: $1960-6060$

\section{Publisher}

Association pour la recherche sur l'Asie du Sud (ARAS)

\section{Electronic reference}

Dalal Benbabaali, "Questioning the Role of the Indian Administrative Service in National Integration", South Asia Multidisciplinary Academic Journal [Online], Free-Standing Articles, Online since 05

September 2008, connection on 21 September 2021. URL: http://journals.openedition.org/samaj/633 ; DOI: https://doi.org/10.4000/samaj.633

\section{(c) (i) (2)}

This work is licensed under a Creative Commons Attribution-NonCommercial-NoDerivatives 4.0 International License. 


\section{samaj South Asia Multidisciplinary Academic Journal}

Benbabaali, Dalal (2008) 'Questioning the Role of the Indian Administrative Service in National Integration', South Asia Multidisciplinary Academic Journal, URL : http://samaj.revues.org/document 633.html. To quote a passage, use paragraph (§).

\section{Questioning the Role of the Indian Administrative Service in National Integration}

Dalal Benbabaali

Abstract. After Independence, the Indian Administrative Service was expected to promote national integration, from a social as well as a spatial point of view. Yet, despite the reservation policy, this elite body lacks representativeness. The partisanship of IAS officers along caste, religious and ethnic lines has further reduced their efficiency as a binding force of the nation. Being an AllIndia Service, the IAS encourages the spatial mobility of its members, which is not always welcome by officers posted in far-off states or in disturbed areas. In these places, the vacancy of postings in the higher administration is a sign of desertion that is contrary to the IAS mission of territorial integration. 
Benbabaali, Dalal (2008) 'Questioning the Role of the Indian Administrative Service in National Integration', South Asia Multidisciplinary Academic Journal, URL : http://samaj.revues.org/document 633.html. To quote a passage, use paragraph (§).

[1] The Indian Administrative Service (IAS) is a prestigious colonial legacy. Its precursor, the Indian Civil Service, was often referred to as the 'steel frame' of British rule in India'. After Independence in 1947, it was still considered a premier institution for maintaining national unity, in a regionally fragmented country with a number of princely states yet to be integrated. The Deputy Prime Minister, Sardar Patel (1875-1950), saw the importance of having a uniform administrative structure and wanted to organise it on a nationwide basis with the central government having a considerable control over it, to counterbalance the emergence of centrifugal forces that could lead to the disintegration of the Indian Union². These proposals were strongly opposed by the Chief Ministers of the states, who wanted no interference with their authority. They favoured the State Civil Services over the All-India Services, which they saw as contrary to the federal principle. But the trauma of the Partition between India and Pakistan pointed to the necessity of providing for a strong centre.

[2] National integration is a double task, not only territorial but also social. While the contribution of the IAS to territorial integration can be assessed through its capacity to contain divisive and separatist aspirations, its role in promoting social integration is partly related to its level of representativeness. Today, there are 5,000 members of the Indian Administrative Service, the highly respected IAS officers, in a country of more than one billion people. The recruitment of this elite body has been democratised through a policy of reservation that guarantees a quota system to the 'backward' castes, traditionally underrepresented in the administration. The Report of the Backward Classes Commission states: 'By increasing the representation of Other Backward Classes in government services, we give them an immediate feeling of participation in the governance of this country' (Government of India 1980: 57).

[3] The importance of having representative bureaucracies in democratic regimes has been highlighted by Kingsley (1944), who questioned the classical Weberian theory of the bureaucrat as an impersonal, discretionless 'single cog in an ever-moving mechanism which prescribes to him an essentially fixed route of march' (Weber 1946: 228). For Kingsley, the neutrality of the bureaucracy is a myth. Administrators come from specific social classes and their

\footnotetext{
${ }^{1}$ The expression 'steel frame' comes from Lloyd George's speech of 1922 in the British Parliament: 'If you take that steel frame out of the fabric, it would collapse. There is one institution we will not cripple, there is one institution we will not deprive of its functions or of its privileges; and that is the institution which built up the British Raj - the British Civil Service of India'.

${ }^{2}$ In his speech to the Constituent Assembly in October 1949, Sardar Patel said: 'You will not have a united India if you do not have a good All-India Service which has independence to speak out its mind'.
} 
Benbabaali, Dalal (2008) 'Questioning the Role of the Indian Administrative Service in National Integration', South Asia Multidisciplinary Academic Journal, URL : http://samaj.revues.org/document 633.html. To quote a passage, use paragraph (§).

behaviour is influenced by their social origin. The only way to avoid the partiality of the bureaucracy is to make it 'democratic', which means 'representative of the groups it serves' (Kingsley 1944: 305). But is there a necessary linkage between the social background of the administrators and the way they take their decisions in office? Mosher (1968) doubts it and establishes a distinction between 'passive (or sociological) representation' and 'active (or responsible) representativeness wherein an administrator is expected to press for the interests and desires of those whom he is presumed to represent, whether they be the whole people or some segment of the people' (Mosher 1968: 11).

[4] In the Indian context of a highly heterogeneous and divided society, where social, religious or regional sense of belonging is sometimes extremely strong and exclusive, 'active representativeness' of the bureaucracy might be a threat to rather than a tool of national unity. The summing up of the multitude of special interests seeking effective representation in the bureaucracy does not constitute the general interest. The different private interest groups within administration are often conflicting and their strengths vastly unequal. The effectiveness of the IAS as a binding force of the nation is thus not only related to its representativeness, but also to its inner cohesion. IAS officers like to portray themselves as a 'new caste' characterised by a strong esprit de corps and horizontal solidarity, but how far is this claim upheld in practice?

[5] This paper aims at assessing the level of integration within the IAS, as well as its capacity to promote national integration in the country. These are two related, though distinct questions. If the bureaucracy is itself divided along caste, religious and regional lines, can it contribute to promote social equality, communal harmony and balanced regional development? To answer these questions, it is relevant to examine not only the social and geographic origins of IAS officers, but also their attitudes, outlook, set of values and overall culture. The statistical analysis presented here is based on primary data collected through a questionnaire addressed to a sample of $50 \%$ of an IAS batch of around a hundred persons ${ }^{3}$, as well as informations regarding a larger pool of officers (500), available in the electronic database of Lal Bahadur Shastri National Academy of Administration (LBSNAA), the IAS training institute, which keeps a

3 The sample is representative of the whole batch in terms of gender, rural/urban breakup, and administrative category (Scheduled Caste, Scheduled Tribe, Other Backward Class, General). To preserve the anonymity of the respondents, the exact year of the batch is not given, but it is one recruited between 2003 and 2006. 
Benbabaali, Dalal (2008) 'Questioning the Role of the Indian Administrative Service in National Integration', South Asia Multidisciplinary Academic Journal, URL : http://samaj.revues.org/document 633.html. To quote a passage, use paragraph (§).

record of all recruits' particulars ${ }^{4}$ since 2001 . The quantitative analysis is completed by qualitative interviews conducted with members of the IAS both under training and in office ${ }^{5}$.

\section{Recruitment: representativeness versus meritocracy?}

[6] In 1854, the British rulers introduced the principle of open competitive examination for entry into the Indian Civil Service (ICS). Although Indians had a right to sit for it, the only examination centre was in London and the system operated as a bar to those who could not afford to travel so far. The Indianisation of the ICS started only in 1922, when the entrance examination was held simultaneously in Allahabad, under pressure from the Indian National Congress. However, the ICS continued to be dominated by the British, and it was often denigrated as 'neither Indian, nor Civil, nor Service'. The 'Brown Sahibs', as the Indian civil servants used to be called, were in a difficult position. During the non-cooperation movement, they were tempted to align themselves with their white masters ${ }^{6}$. Hence, after Independence the loyalty of ICS officers was suspect. Public opinion was generally hostile to the ICS in view of its identification with foreign rule and its obstructing role during the freedom struggle. But Sardar Patel, the leader of the conservatives in Congress, did ultimately succeed in forcing his proposals down the throat of an unwilling Constituent Assembly. He advocated the importance of administrative continuity for the stability of the country. Finally, the institution was maintained under a new name, the Indian Administrative Service.

[7] From enforcement of law and order and collection of revenue, the post-independence civil service has grown as an important tool for implementing national and state policies of welfare and planned economic development. These new tasks and objectives led to an increase in the size of the bureaucracy. There was an urgent need to organise new recruitments after the depletion caused by the resignation of British civil servants and the emigration to Pakistan of many Muslim officers. Since Independence, the Union Public Service Commission (UPSC), in charge of the centrally-organised recruitment, conducts every year a combined civil service

\footnotetext{
${ }^{4}$ This database is confidential but I was kindly allowed to access it for research purpose. It comprises personal information on recruits, such as gender, age, place of birth, administrative category, religion, educational background, marital status, language used for written and oral entrance examination.

${ }^{5}$ These interviews were conducted during my stay in LBSNAA for one whole year as a French teacher in 2003-2004, and during shorter stays in the next two years as a researcher. I also interviewed senior officers posted in the field.

6 'As a rule the foreign government can rely upon the 'native' civilian to be more zealously oppressive than even the average Anglo-Indian official' Aurobindo Ghosh, 1908 (quoted in Gupta 1996: 29).
} 
Benbabaali, Dalal (2008) 'Questioning the Role of the Indian Administrative Service in National Integration', South Asia Multidisciplinary Academic Journal, URL : http://samaj.revues.org/document 633.html. To quote a passage, use paragraph (§).

competitive examination on a nationwide basis. The minimum qualification demanded of eligible candidates is a Bachelor's degree in any discipline from any recognised university. Half of the seats are reserved for the depressed classes. The reservations for Scheduled Castes (SC) and Scheduled Tribes (ST) are equal to their proportion in the total population, respectively 15 and $7.5 \%$. The Other Backward Classes $(\mathrm{OBC})$, who are more than half the Indian population, have benefited since 1993 from $27 \%$ of reserved seats, as the quota totals should not exceed $50 \%$, according to a Supreme Court order aiming at preserving the merit principle. Affirmative action for SCs and STs is a constitutional provision and is relatively well accepted by the rest of the population, since it has never threatened to revolutionise the social order. In contrast, the extension of civil service quotas for OBCs at the beginning of the 1990s created violent reactions among the upper castes. They protested against the loss of their hegemonic position in the higher administration, which they regarded as their monopoly, and against the challenging of a sociopolitical order they had always dominated. Their anger lessened as the opening up of the Indian economy was offering them new avenues for employment in the private sector. But in 2006, the project of Manmohan Singh's government to extend the reservations for OBCs to the higher educational institutes (the Indian Institutes of Technology, the Indian Institutes of Management, the medical colleges), and to the private sector, gave a new impetus to the anti-reservation movement. Upper caste students argue that the quota system is contrary to the merit principle and jeopardises performance.

[8] In the administration, the argument of meritocracy versus reservations is very controversial, since the objective is to make the bureaucracy both efficient and representative. In fact, the candidates recruited through reservations are no less meritorious, since they are also selected through an extensive and rigorous examination process. The civil service competitive examination takes place in three stages during one whole year. The preliminary test was introduced to weed out non-serious contenders among the 100,000 candidates who sit for it every year on average. Only $10 \%$ are selected for the main examination, which consists of written papers, some compulsory, like English, one Indian language, and one essay, and some optional, which the candidates can choose from a long list of subjects taught in the universities. After this second stage, $10 \%$ of the candidates are again selected, which means that approximately one thousand people are called for the final stage, the oral interview. It is a personality test conducted by an expert panel which judges the candidates' motivation, presence of mind, and leadership qualities, apart from their intellectual capabilities and aptitude for the work involved. In this final 
Benbabaali, Dalal (2008) 'Questioning the Role of the Indian Administrative Service in National Integration', South Asia Multidisciplinary Academic Journal, URL : http://samaj.revues.org/document 633.html. To quote a passage, use paragraph (§).

round of elimination, half of the candidates are declared successful. Ultimately, less than $0.5 \%$ of the candidates are selected and only the higher ranking can opt for the Indian Administrative Service, leaving the less prestigious services to the others ${ }^{7}$.

[9] During the interview, the only stage of the competition when the candidates lose their anonymity, some people complain of discrimination, not directly because of their social background, but because of their choice to speak in their mother tongue instead of English. Yet, this choice has been authorised since the 1970s for the 18 regional languages officially recognised in the 8th Schedule of the Constitution. The objective was to broaden the social and geographic basis of the recruitment, by enabling people without access to English education to compete. The preference of the examiners for English-speaking candidates, according to many recruits, might be motivated by purely academic and professional reasons, but some people interpret it as a bias in favour of the urban middle-class candidates, who are already overrepresented in the IAS.

\section{Educational profile, social and geographic origins of IAS officers}

[10] The recruits of the IAS belong to an educational elite, as well as a social elite, since even the lower caste candidates are usually part of the 'creamy layer's. From the primary level, there is a gap between the urban middle-class children who are sent to private English-medium schools, preferably to Christian missionary schools, and the rural children who attend the village public schools, and who are taught in vernacular. Two-thirds of the IAS officers of the surveyed sample did their primary education in cities, whereas $72 \%$ of the Indian population live in rural areas. $40 \%$ of the IAS officers studied in private schools, half of them in convent schools. One third studied in English-medium schools at the primary level, but two-thirds at the secondary level.

[11] As far as higher education is concerned, $60 \%$ of the interviewed IAS are postgraduates, holding a Master's degree and sometimes even a PhD, whereas a simple graduation is enough for eligibility in the civil service examination. Those who fail at the first attempt, in fact

\footnotetext{
${ }^{7}$ There are however two other prestigious services, the Indian Foreign Service (IFS) and the Indian Police Service (IPS), for which the candidates generally opt as a second choice just after the IAS.

${ }^{8}$ The 'creamy layer' is now an official category defined by strict criteria of annual income and occupation (sons and daughters of higher civil servants, of judges of Supreme Court and High Courts, of large landowners, and so forth). The concept does not apply to SC and ST candidates who can still benefit from reserved seats even if they belong to this category, but $\mathrm{OBC}$ candidates coming in the creamy layer are not entitled to reservations.
} 
Benbabaali, Dalal (2008) 'Questioning the Role of the Indian Administrative Service in National Integration', South Asia Multidisciplinary Academic Journal, URL : http://samaj.revues.org/document 633.html. To quote a passage, use paragraph (§).

the majority, and who want to sit again for the examination, generally pursue their studies in the meantime. That is why so many candidates are overqualified at the time of selection. The average age of entry into the civil service, which is now 27 years, has increased because of longer studies. The age limit for eligibility has been progressively extended to 30 years (with concessions for reserved categories), while it was only 24 during the two decades following Independence. Until the 1980s, the university profile of the IAS officers used to be homogeneous and primarily based on humanities (Subramaniam 1971). But among the IAS recruited between 2001 and 2005 , only one third were arts graduates, $13 \%$ science graduates, the majority holding a professional degree, with $25 \%$ engineers, $15 \%$ medical doctors, $8 \%$ managers (MBAs) and $6 \%$ lawyers (LBSNAA database). Economic reforms and more remunerative employment opportunities in the private sector were expected to make the civil service less attractive. Yet, the prestige of the civil service is still very high, and its members enjoy a status and influence in society that compensate for their comparatively low salaries ${ }^{9}$. Some young professionals even quit their job to join the IAS. As one of them states: 'Even if I become the CEO of my company, I am still a nobody in the eyes of the public, I have no social recognition on a large scale. When I go out, I am anonymous. But as an IAS, if I go to visit a village, the whole population will be out to welcome me'. Others explain that they wanted to have a professional degree to be able to find a job in case they could not succeed in the civil service examination.

[12] A trend that has gained momentum in the past decade is the growing importance of private coaching classes to prepare for the civil service examination. The fees are usually high and infringe upon the merit principle of the recruitment by reducing its socio-spatial basis. Candidates who cannot afford it, or who live far from the metropolitan cities where these coaching centres are available, find themselves increasingly at a disadvantage. That is why the state governments are now developing their own coaching centres, generally free of cost for the underprivileged classes, to give equal opportunity to all candidates. More than one third of the IAS recruited since 2001 have a rural background (LBSNAA database), even if it is still far from being representative of the whole Indian population, who is mostly rural.

[13] In the 1950s and 1960s, most of the high-level civil servants were drawn from the well-off urban classes and belonged to the upper castes. While they form less than $6 \%$ of the

\footnotetext{
${ }^{9}$ Even though IAS salaries increased between 1991 and 2001 (Das 2005), they are still much lower than those of their counterparts in the private sector. While an IAS officer starts with a salary of 15,000 rupees per month, an engineer can easily get twice this amount at the beginning of his career.
} 
Benbabaali, Dalal (2008) 'Questioning the Role of the Indian Administrative Service in National Integration', South Asia Multidisciplinary Academic Journal, URL : http://samaj.revues.org/document 633.html. To quote a passage, use paragraph (§).

Indian population, Brahmins were long overrepresented in the IAS where they occupied $40 \%$ of the seats on the average (Subramaniam 1971). The Brahmin hegemony in the higher civil service was challenged by the introduction of reserved seats for OBCs in the 1990s. After the Brahmins, the most represented in the IAS used to be the literary castes of scribes (Kayasth). Coming next were the upwardly mobile landowning castes who had invested in their children's education. Some of them were later classified as $\mathrm{OBCs}$, but the prosperous agrarian dominant castes are not entitled to reservations. They are nevertheless well represented in the IAS. In the beginning, the quotas for Scheduled Castes and Scheduled Tribes were rarely filled, due to lack of qualified candidates. With the spread of education among them and the emergence of a middle class coming from lower castes, the reserved posts are presently being filled. In the surveyed sample of 50 IAS officers, 6 were Brahmins, 5 Kshatriyas (mostly Rajput), 4 Banias, 10 from agrarian dominant castes (Jat, Bhumihar, Kamma), 15 OBCs (Kurmi, Yadav, Naidu, Christians and Muslims), 7 SCs (Chamar, Mahar, Mala) and 3 STs (Banjara, Irukala, Kishan).

[14] Forming the bulk of the Indian population (82\%), Hindus are overrepresented in the IAS, with $88 \%$ of recruits in average (LBSNAA database). The Christian, Sikh and Jain minorities are also overrepresented, whereas Muslims are clearly underrepresented in the IAS, with less than $3 \%$ of recruits, while Islam is the religion of $12 \%$ of the population. The underrepresentation of Muslims in the IAS has historical reasons, since after the Partition a large number of Muslim elites left India for Pakistan. Moreover, the Muslim community invested more in trading jobs than in education, maybe out of fear of discrimination in white-collar jobs. Muslim teaching institutions suffer from their poor adaptability and from the decline of Urdu, their literary language.

[15] The vast majority of IAS officers comes from the middle class. In the surveyed sample, 30 declare that they belong to the lower middle class, and 13 to the upper middle class. 5 say that they come from rich families and 2 from poor families. In order to verify these statements, which are based on self-perceptions, the officers were asked about their father's occupation. As shown in Figure 1, only one person belongs to the working class, whereas 9 hail from business families. 7 are children of middle or rich landowning farmers. For 11 of the interviewed officers, the father's occupation belongs to the lower intellectual professions (clerks, school teachers), and for another 8 to the higher intellectual professions (professors, doctors). 14 are sons or daughters of civil servants, which reveals the existence of social reproduction. But the merit principle of the competitive examination also allows upward mobility, as the sizeable number of officers whose 
Benbabaali, Dalal (2008) 'Questioning the Role of the Indian Administrative Service in National Integration', South Asia Multidisciplinary Academic Journal, URL : http://samaj.revues.org/document 633.html. To quote a passage, use paragraph (§).

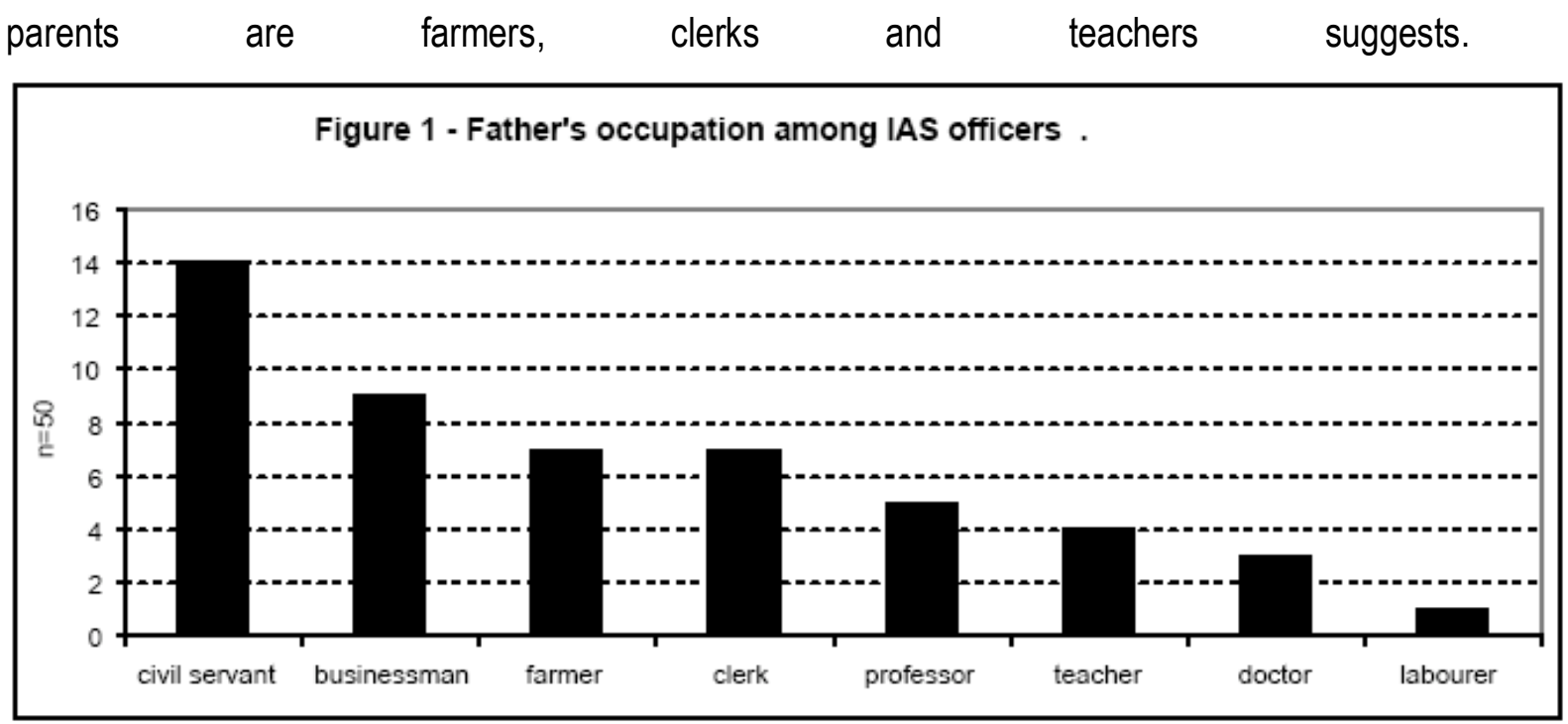

\section{Source: personal investigation on an IAS batch sample.}

[16] After Independence, there were hardly any women in the higher civil service. Now female recruits represent approximately one fourth of each IAS batch, and their profile is more elitist than the average. They are often top rankers in the civil service competitive examination and come mostly from the well-off urban classes and upper castes. Among the women recruited in the IAS between 2001 and 2005, less than 15\% had a rural background, as against $43 \%$ among the men (LBSNAA database).

[17] There are striking imbalances regarding the distribution of IAS officers by state of origin (Figure 2). The recruitment on a national basis aims at selecting the best talent available in the whole Indian territory regardless of the geographic origin of the candidates. However, for an All-India Services designed to contribute to national integration, it seems important that each of the different states should have an adequate representation. 
Benbabaali, Dalal (2008) 'Questioning the Role of the Indian Administrative Service in National Integration', South Asia Multidisciplinary Academic Journal, URL : http://samaj.revues.org/document 633.html. To quote a passage, use paragraph (§).

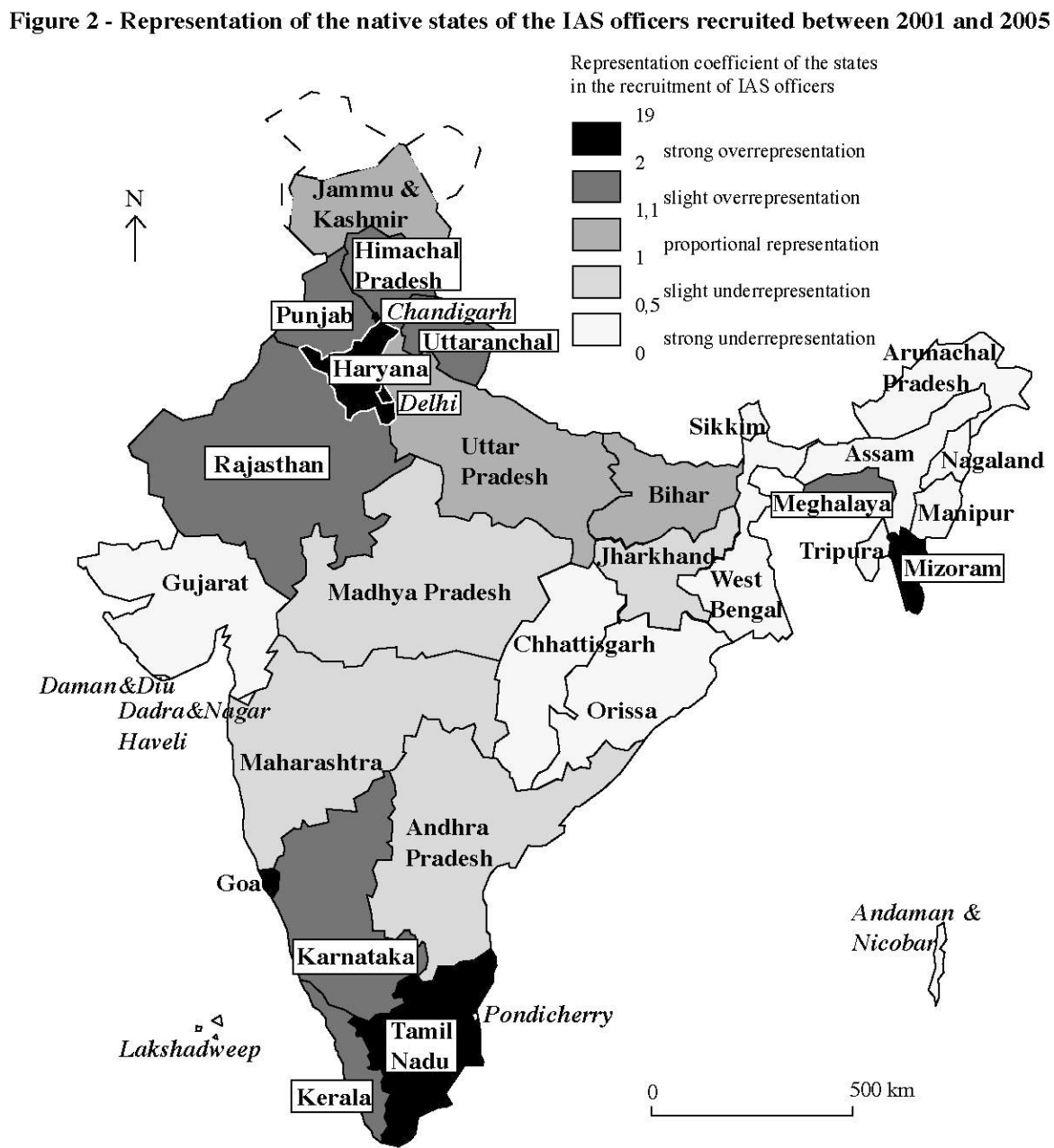

(C) D. Benbabaali (2006)

Source : Census of India 2001, Lal Bahadur Shastri National Academy of Administration database (2001-2005)

[18] Rajasthan, Uttar Pradesh and Bihar are relatively poor states but are well represented in the IAS, because in these states the prestige of the civil service is very high and many candidates try their luck every year by sitting for the examination. As a Bihari officer explains: 'After my graduation from Patna university, I left Bihar for Delhi where I did a Master degree at the Jawaharlal Nehru University while preparing for the civil service examination. Many of my classmates in Patna did the same because there are very few jobs in the private sector in Bihar, and there the civil service commands a lot of respect'. By contrast, states like Gujarat, Maharashtra and Andhra Pradesh are more developed, their educational structures are better, and thus their success ratio in the civil service exam might be higher, but there are fewer candidates since these states offer many other avenues for employment to their best students, who can take up private jobs. That is why there is no clear connection between the development level of a state and its representation in the IAS. 
Benbabaali, Dalal (2008) 'Questioning the Role of the Indian Administrative Service in National Integration', South Asia Multidisciplinary Academic Journal, URL : http://samaj.revues.org/document 633.html. To quote a passage, use paragraph (§).

[19] Among the overrepresented states, Tamil Nadu is more urbanised than the average. Statistically candidates with an urban background appear more and have a higher success ratio in the civil service examination. That is why Delhi and Haryana, as well as Chandigarh, a fully urbanised territory, are still strongly overrepresented in the IAS, even after the development of regional universities has counterbalanced the share of Delhi in the recruitment of IAS officers. The states with an important tribal population like Chhattisgarh and Orissa, as well as the NorthEastern states, are strongly underrepresented, except Meghalaya and Mizoram, where Christian missionaries have encouraged education of the 'tribal' indigenous groups, who were thus able to benefit from the quotas for STs.

[20] The profile of IAS officers is very diverse, even if this elite body is far from reflecting the diversity of the whole Indian population. What has been examined up to now is the 'passive', or sociological, representativeness of the IAS, which can be measured in statistical terms. One has to turn now to the question of 'active' representation, which cannot be measured quantitatively, but can be assessed through interviews and observation of individual behaviour. 'Passive' representation plays an important role in national integration, especially at the symbolic and psychological level, since the different social and regional groups get the feeling that they participate indirectly in public affairs. As the Report of the Backward Classes Commission states, when a backward class candidate becomes a Collector or a Superintendent of Police, (...) the psychological spin off of this phenomenon is tremendous; the entire community of that backward class candidate feels socially elevated. (...) The feeling that now it has its 'own man' in the 'corridors of power' acts as morale booster' (Government of India 1980: 57).

[21] But the role of 'active' representation is more ambiguous. How far can administrators coming from specific social or regional groups actively represent the interests of their community once vested with power? Is the bureaucracy not supposed to serve everyone in society evenhandedly in the interest of the general public, without showing any partiality or favouritism? The first rule of conduct of the IAS officers is indeed to act with strict impartiality and objectivity. During the extensive debate for the framing of the Constitution, Sardar Patel made it a point that civil servants should be politically neutral and should preferably work outside their state to avoid interference from their community members. Political neutrality, fight against casteism, 
Benbabaali, Dalal (2008) 'Questioning the Role of the Indian Administrative Service in National Integration', South Asia Multidisciplinary Academic Journal, URL : http://samaj.revues.org/document 633.html. To quote a passage, use paragraph (§).

regionalism, communalism ${ }^{\mathbf{1 0}}$ : such is the IAS ethic of public service. But how far is it upheld in practice?

\section{Training in the National Academy of Administration: promoting social and regional intermingling}

[22] Once recruited, IAS officers undergo compulsory training at Lal Bahadur Shastri National Academy of Administration (LBSNAA) in Mussoorie, a small town in the foothills of the Himalayas. Before the relocation of the institute in 1959, they were trained in Delhi. There has always been considerable bureaucratic pressure in favour of bringing the Academy back to the national capital (Maheshwari 2005). But Delhi is already a crowded metropolis, and the governmental policy is rather to keep away the new entrants to the civil service from the Central Secretariat, where they would be exposed from the very beginning to the existing factions and lobbies in the administration, and tempted to evince interest in matters of postings and promotions. More importantly, IAS officers belong to an All-India Service basically designed for the states. Training them at the seat of the central government would be unwise, since an initial stay in Delhi would encourage the already existing trend of asking for a deputation to the Centre when not satisfied with a posting in the states.

[23] Under British rule, the members of the Indian Civil Service were given a high standard of training at the East India College of Haileybury in England (Mason 1985). Now, IAS officers are sent for a one-year course at the Academy of Mussoorie, where they are taught public administration, law, economics, history, geography and one Indian language apart from their mother tongue. But beyond this academic course, the faculty members, who are often themselves IAS officers, try to develop an esprit de corps among their young colleagues, in spite of their different backgrounds. They encourage the IAS probationers coming from different regions to mingle, as reflected in the rules of room allocation in the hostels. A North Indian probationer generally shares his or her room with a South Indian, and they sometimes need to use English to be able to communicate. Many of them say that their stay in the Academy is their first exposure to the diversity of the Indian population. $90 \%$ of the probationers of the surveyed

\footnotetext{
${ }^{10}$ Communalism is the term used in India to describe the exclusive feeling of religious belonging which
} leads to the violent exclusion of other religious communities. 
Benbabaali, Dalal (2008) 'Questioning the Role of the Indian Administrative Service in National Integration', South Asia Multidisciplinary Academic Journal, URL : http://samaj.revues.org/document 633.html. To quote a passage, use paragraph (§).

sample have never left their home state before higher education. But half of them went to the university in a different state, most of the time to a neighbouring one or to Delhi.

[24] To help expose the probationers to the cultural diversity of their country, artists from various parts of India are invited to the Academy to perform music, dance and theater programmes. Moreover, village visits are organised to sensitise the officer trainees to the reality of rural India, since most of them have never lived in a village. They also go for a ten-day trek in the Himalayas in small autonomous groups. The objective of this tough expedition is to strengthen their esprit de corps, despite their linguistic, religious or caste differences. Last but not least, they are sent on a two-month study tour throughout India, which is the biggest exposure to the immensity and diversity of their country that most of the probationers ever had. This trip is intended to give them an all-India perspective and a global picture of the territory they are going to administer. After completion of the course in the Academy, the IAS probationers are sent to the districts for a one-year practical training in the state to which they have been assigned ${ }^{11}$. Then they go back to the Academy for two more months in order to compare their respective experiences in the field and to report to the faculty members about the administration problems they have come across.

[25] By observing the behaviour of the probationers during these different stages of their training and discussing with them, one can point out the shortfalls of social and regional integration within the IAS. In the Academy, although it is possible to make the probationers mingle in the hostels, it is not the case in the canteen. Vegetarians, generally Brahmins or uppercaste people, eat apart from non-vegetarians. Besides, each regional group, speaking a common language, usually sit together at a table. $90 \%$ of the interviewed probationers admit that the groups are formed most often according to ethno-linguistic origin, and non-Hindi speakers, especially South Indians, are criticised for being clannish and chauvinistic about their mother tongue. But one should not draw general conclusions from this regional groupism, which is quite natural. A more disquieting feature is the favouritism shown by some faculty members to the probationers coming from their state, according to the statement of many officer trainees.

[26] Communal tensions rarely occur in the Academy. Forming a tiny minority, Muslim probationers adopt a low profile, but they sometimes have to face remarks about Hinduism being

11 This period of training in the field is the subject of Chatterjee's novel, English August, a humorous portrayal of a typical urban, English-educated IAS officer, who discovers with disillusionment and boredom the Indian realities in a remote rural district (Chatterjee 1988). 
Benbabaali, Dalal (2008) 'Questioning the Role of the Indian Administrative Service in National Integration', South Asia Multidisciplinary Academic Journal, URL : http://samaj.revues.org/document 633.html. To quote a passage, use paragraph (§).

the true cement of national unity or questioning the loyalty of Muslims to the Indian nation. Within the IAS, the influence of Hindu nationalist movements is much more prevalent than is openly admitted. One of the most famous coaching centres preparing for civil service examination ('Sankalp') is entirely funded by the RSS, an anti-Muslim organisation, which thus controls a powerful tool to propagate its ideology within the future elites of the administration. The importance of communalism in the higher civil service appeared clearly during the 2002 riots in Gujarat, which cost the lives of more than a thousand Muslims. The paralysis of the administration and its failure to contain the pogrom revealed the silent complicity of some politicians and bureaucrats with the Hindu fundamentalists (D'Souza 2002).

[27] Casteism is not very apparent in the Academy, but it is still a reality that weighs in the career of IAS officers once in the field. In the Academy, untouchability is not any more an open practice like in the 1950s and 1960s, when some lower-caste officers chose to resign because of the prejudices they had to face (Singh 1964). Now it is a much more subtle practice, which is often self-imposed. Many lower-caste probationers prefer to keep aloof from others in order not to face the scornful attitude of some of their colleagues. Conflicts are never open, unless a particular incident happens. When, for example, a group of probationers organised the birthday celebration of the untouchable leader Ambedkar in the Academy, the deliberate absence of some of their upper-caste colleagues created some tensions. Once posted in the field, caste often plays a part in transfers and promotions ${ }^{12}$. The competition between IAS officers is fierce, since only a minority can reach the higher posts of the administration, in the Secretariat and in the ministries. Merit and seniority are not the only considerations in career advancement. Disguised discrimination is a common practice and incompetent officers are sometimes promoted only because of their caste identity.

[28] Casteism, communalism and regionalism affect the performance of the higher administration. The divisions in Indian society are not only reflected in the ranks of the bureaucracy, but because of the partiality of some of its members, the bureaucracy might also contribute to reinforcing social divisions. The Gujarat example has shown how the inaction of the police and of the administration can cost the lives of thousands of people. Similarly, the press reveals sometimes how the perpetrators of atrocities against untouchables are not prosecuted in the districts where the Superintendent of Police and the District Magistrate prefer to turn a blind

12 'While transfers in the 1960s were more a matter of administrative routine, they are now increasingly being ordered on the basis of caste, influential networks and political loyalties' (Banik 2001: 111). 
Benbabaali, Dalal (2008) 'Questioning the Role of the Indian Administrative Service in National Integration', South Asia Multidisciplinary Academic Journal, URL : http://samaj.revues.org/document 633.html. To quote a passage, use paragraph (§).

eye to those matters. Moreover, caste favouritism leads to unequal allocation of resources and to misappropriation of government funds at the expense of the target groups, that is, the underprivileged sections of society. To explain this practice, the bureaucrats accuse local politicians of pressuring them to serve as a priority their 'clients', that is their specific electorate. As a young Collector admits: 'If a Minister or a local MLA ${ }^{13}$ gives me 10 names which should be considered first for the distribution of a government scheme, I have to accept at least 5 of them, only then can I serve those who really need this scheme and who are eligible for it'.

[29] This being said, there is one striking feature observed in the Academy that can contribute to fostering national integration is a trend of inter-religious, intercaste and interregional marriages among officers. IAS women generally prefer to marry another officer within the profession, because, as some of them explain, 'it is otherwise difficult to find a husband who would accept his wife having a more prestigious job than his'. This social 'homogamy'14 is less strong among IAS men, since they are aware of their value on the matrimonial market. They can get a huge dowry by marrying the daughter of a rich industrialist, a powerful politician or a senior bureaucrat. Dowry was officially forbidden in 1961 (Anti-Dowry Act), but it seems to be a growing phenomenon. The amount varies according to the occupation of the husband and to his caste.

[30] In India, it is widely considered that IAS officers occupy the highest position on the dowry market. $40 \%$ of the interviewed officers declared that they were offered more than ten crores (hundred millions) of rupees as a dowry, especially in the form of immovable property, but only half of them admitted that they actually took it. In these conditions, one may assume that those who can afford to have an IAS as a son-in-law are mostly well-off businessmen or corrupt politicians and bureaucrats. The officers use this fact to elevate their social status through marriage. Coming generally from the middle class, most of them marry in the upper classes of society. The dowry they get is sometimes so huge that they can recycle part of it to marry their sisters to good matches and thus elevate the position of the whole family. These practices are all the more illegal as black money is often used for dowry (what bureaucrat or politician can honestly earn the millions spent on his daughter's marriage with a monthly salary of only tens of thousands rupees?). Dowry is in a way the first bribe that a male IAS gets in his career. It is offered to him by a rich and powerful family in exchange for services ('I can help my people to get

\footnotetext{
${ }^{13}$ Member of the Legislative Assembly.

14 'Homogamy' is the term used by Bourdieu (1989) and other sociologists to describe marriages within the same profession.
} 
Benbabaali, Dalal (2008) 'Questioning the Role of the Indian Administrative Service in National Integration', South Asia Multidisciplinary Academic Journal, URL : http://samaj.revues.org/document 633.html. To quote a passage, use paragraph (§).

their work done', says one of them). Through his title, the IAS officer can also give his in-laws the social recognition and respectability that they lacked despite their wealth.

[31] Between 2001 and 2005, among 170 IAS officers on whom marriage data could be collected, $45 \%$ had a typical arranged marriage, within the caste, and generally with dowry. $40 \%$ made a love marriage, most of the time without dowry, and without consideration of caste, creed or region. This proportion is much higher than the national average, since in India the immense majority of marriages are arranged by the families within the same caste. IAS women usually do not give dowry, so marriages between officers are either love marriages or cadre-based marriages. The All-India Services follow a cadre system wherein the officers are allotted various states (cadres) during their probationary period, to which they remain affiliated throughout their career. Getting married to another member of the All-India Services with a 'better' cadre is the only way to change one's state of allotment by joining the spouse's cadre: this is called cadrebased marriage. They represent $15 \%$ of the marriages on which information was given. The career of an IAS can indeed vary considerably according to the state cadre to which one has been assigned, where the officer has to stay most of his or her professional life. Some of them are posted very far from their home state or in 'inhospitable' places, and they are therefore ready to do anything to get a 'better' cadre. One young lady officer posted in the North-East explains her marriage plans: 'My parents wanted me to marry within the caste, but now a cadre-based marriage is the only option for me. No well-settled man from my community would leave everything and go with me to the North-East. Life is difficult there, even for me. To be transferred, I have no choice but to marry an officer from the All-India services. I still have to find somebody with a good posting who would accept to take me out of my cadre, but he might be neither from my caste nor from my state'.

\section{Cadre allocation: fostering spatial mobility}

[32] The IAS is an All-India Service that ensures an equitable mix of 'insider' and 'outsider' officers in each state. Half of the vacancies go to officers who come from the state, and the other half to officers from other regions. Among insiders, 33\% are promoted from the State Civil Service. There are thus few home cadre vacancies for the IAS officers directly recruited through the national examination, which is why most of them are posted to a state different from their native one. It is a deliberate policy, which aims at encouraging the spatial mobility of high- 
Benbabaali, Dalal (2008) 'Questioning the Role of the Indian Administrative Service in National Integration', South Asia Multidisciplinary Academic Journal, URL : http://samaj.revues.org/document 633.html. To quote a passage, use paragraph (§).

level civil servants and at promoting national integration by giving the officers an all-India outlook. The objective is also to break down local patron-client networks and avoid parochial pressures on administrators, who are continually exposed to forces drawing sustenance from caste, religion, region, language. It is easier not to succumb to these demands for 'outsiders', who are usually more immune to them and more neutral than 'insiders'.

[33] But some state governments are not keen on receiving civil servants 'imposed' by the central government, especially since the end of the Congress hegemony and the emergence of opposition regional parties. The pan-Indian character of the IAS is sometimes considered incompatible with the federal principle, an erosive force acting against the autonomy of the states, while its members are viewed as the agents of the central government in the regions. Between 1975 and 1977, during the National Emergency declared by Indira Gandhi, high-level civil servants zealously collaborated with the authoritarian regime ${ }^{15}$, which made them suspect in the eyes of state politicians (Appu 2005). In 1977, in a memorandum on centre-state relations, the communist government of West Bengal stated that the All-India Services must be abolished. Eight years later, three other states (Tamil Nadu, Tripura and Punjab) expressed the same view. But the issue of dismantling the All-India Services was never seriously considered by the central government because the principle of the integrative role of national bureaucracy has prevailed up to now.

[34] The All-India Services are jointly controlled and managed by the Centre and the States. The central government, through the Ministry of Personnel, has a considerable say in the careers of IAS officers. A system of rotation enables the civil servants to work successively in the state of their allotment and at central level in New Delhi. The first ten years are usually spent in the districts, at the grass roots level, until the officers reach the position of Collector (also called District Magistrate). Then they can ask for a deputation to the Centre. Back to their cadre, they usually stay in the state capital and work in the Secretariat. The highest office they can hold at the regional level is that of Chief Secretary, a rank that only a few reach.

[35] In the states, the Chief Minister, at the head of the regional government, possesses a triple prerogative on IAS officers: he can transfer them from one district to another, promote and suspend them. Transfers are a normal feature in personnel administration, according to the

15 'Evidence which appeared in the Shah Commission of Inquiry Reports after the Emergency suggests that most IAS officers in the Secretariat and districts (...) accepted orders they believed to be improper and politically motivated' (Potter 1996: 156). 
Benbabaali, Dalal (2008) 'Questioning the Role of the Indian Administrative Service in National Integration', South Asia Multidisciplinary Academic Journal, URL : http://samaj.revues.org/document 633.html. To quote a passage, use paragraph (§).

Weberian concept of separation of the incumbent from the office he is holding. They prevent the growth of excess 'embeddedness' (Evans 1992) in local society by creating some distance between the administrators and the public. But some minister-politicians misuse their power and try to make non-submissive bureaucrats pliable by transferring them to 'punishment' postings, in remote or insurgency-affected areas. This phenomenon helps to explain the collusion of interests between corrupt bureaucrats and politicians. Some IAS officers use intense lobbying and offer bribes to their political masters in order to secure a lucrative or 'plum' posting, through which they can easily reimburse themselves thanks to the discretionary power vested in it and to the large resources at their disposal (Wade 1985, Arora and Radin, 2000). As early as 1964, the Santhanam Committee Report pointed out the connection between transfers and corruption. The increase in allegations of corruption against IAS officers is reflected in the Central Vigilance Commission reports (Government of India 2001), and brings disrepute to the once famed and sacrosanct office ${ }^{16}$. The IAS has consequently fallen steeply in public esteem.

[36] Despite the nexus between politicians and bureaucrats, the latter are always in a precarious position since they can be arbitrarily transferred at any time, especially if they threaten certain local vested interests (Banik 2001). Quoting the example of the Gujarat anti-Muslim riots, D'Souza (2002) observes: 'Perversely, officers of integrity who, in applying the law diligently, act against offenders aligned with the ruling party in the government, suffer the harassment of repeated transfer'. Whenever there is a change of government in the states, the civil servants have to face large scale transfers. Uttar Pradesh, with a dozen changes of government between 1977 and 1999, is considered to be the state where the average tenure of the administrators is the shortest and where mass transfers have been largely institutionalised ${ }^{17}$. This chronic instability affects the performance of the administration, which needs continuity to achieve organisational objectives.

[37] 'Political interference', as bureaucrats name it, varies from state to state. In the Indian federal set-up, the state governments differ largely in terms of political and administrative

\footnotetext{
${ }^{16}$ Forster, in his novel A Passage to India, written in 1924, reminds us with much humour that the British civil servants working in India were not more incorruptible than Indian civil servants, but they were less easily caught: 'When we poor blacks take bribes, we perform what we are bribed to perform, and the law discovers us in consequence. The English take and do nothing. I admire them' (Forster 2005: 6).

17 In Uttar Pradesh, Chief Minister Kalyan Singh transferred 293 IAS officers between July 1991 and December 1992. His successor, Mulayam Singh Yadav transferred 321 IAS between December 1992 and June 1995, and Mayawati 284 IAS between June and October 1995 ('UP-wardly Mobile', The Indian Express, 2 July 1998).
} 
Benbabaali, Dalal (2008) 'Questioning the Role of the Indian Administrative Service in National Integration', South Asia Multidisciplinary Academic Journal, URL : http://samaj.revues.org/document 633.html. To quote a passage, use paragraph (§).

culture. This is one of the criteria that IAS officers take into account when they talk of 'good' or 'bad' cadres. In the Academy, it is a common topic of conversation and it is interesting to study the perception of the Indian territory by its administrators. Which state they are allotted is a very important issue for them and carries enormous personal meaning because their entire careers are at stake. Cadres are allotted randomly in order to treat all the states equally. Recruitment and random cadre allocation on a national basis is a way to promote national integration, since the smaller or less developed states may not be able to attract highly qualified civil servants to their territory. Merit is taken into account only for home cadre allocation, since most IAS officers wish to be posted in their own state.

[38] $95 \%$ of the interviewed IAS put their home state as a first choice when asked: 'If you could choose your cadre, what would be your first five choices?'. For the next choices, the three states that were most frequently mentioned were Maharashtra, Karnataka and Andhra Pradesh. These states are generally considered as 'good cadres' because they are big and among the most developed of India. But the development level of a state comes into consideration both ways, since comparatively backward states like Rajasthan, Madhya Pradesh and Uttar Pradesh offer different types of advantages to the officers, especially in terms of prestige and power. According to one probationer, 'in these 'feudal' states, IAS officers are considered as Ma-Bap ${ }^{18}$ of the people, if not as demigods. Moreover, illiterate people don't create as much trouble as the educated, like in Kerala where people know their rights and keep on fighting for them'. This can explain why backward states are also frequently mentioned in the list of cadre wishes (Figure 3).

${ }^{18}$ Mother and father. 
Benbabaali, Dalal (2008) 'Questioning the Role of the Indian Administrative Service in National Integration', South Asia Multidisciplinary Academic Journal, URL : http://samaj.revues.org/document 633.html. To quote a passage, use paragraph (§).

Figure 3 - Cadre preferences of IAS officers

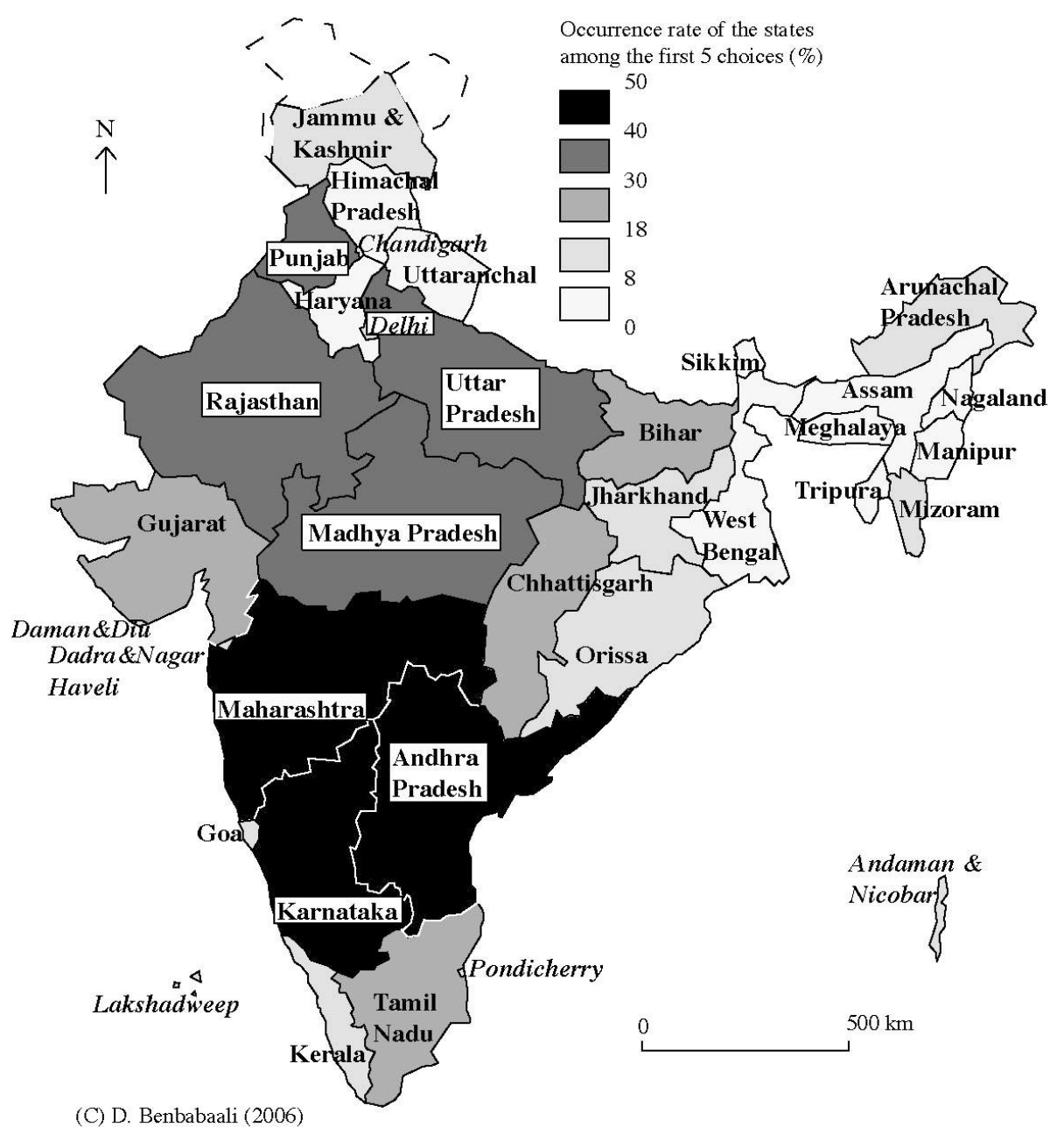

(C) D. Benbabaali (2006)

Source : personal investigation 
Benbabaali, Dalal (2008) 'Questioning the Role of the Indian Administrative Service in National Integration', South Asia Multidisciplinary Academic Journal, URL : http://samaj.revues.org/document 633.html. To quote a passage, use paragraph (§).

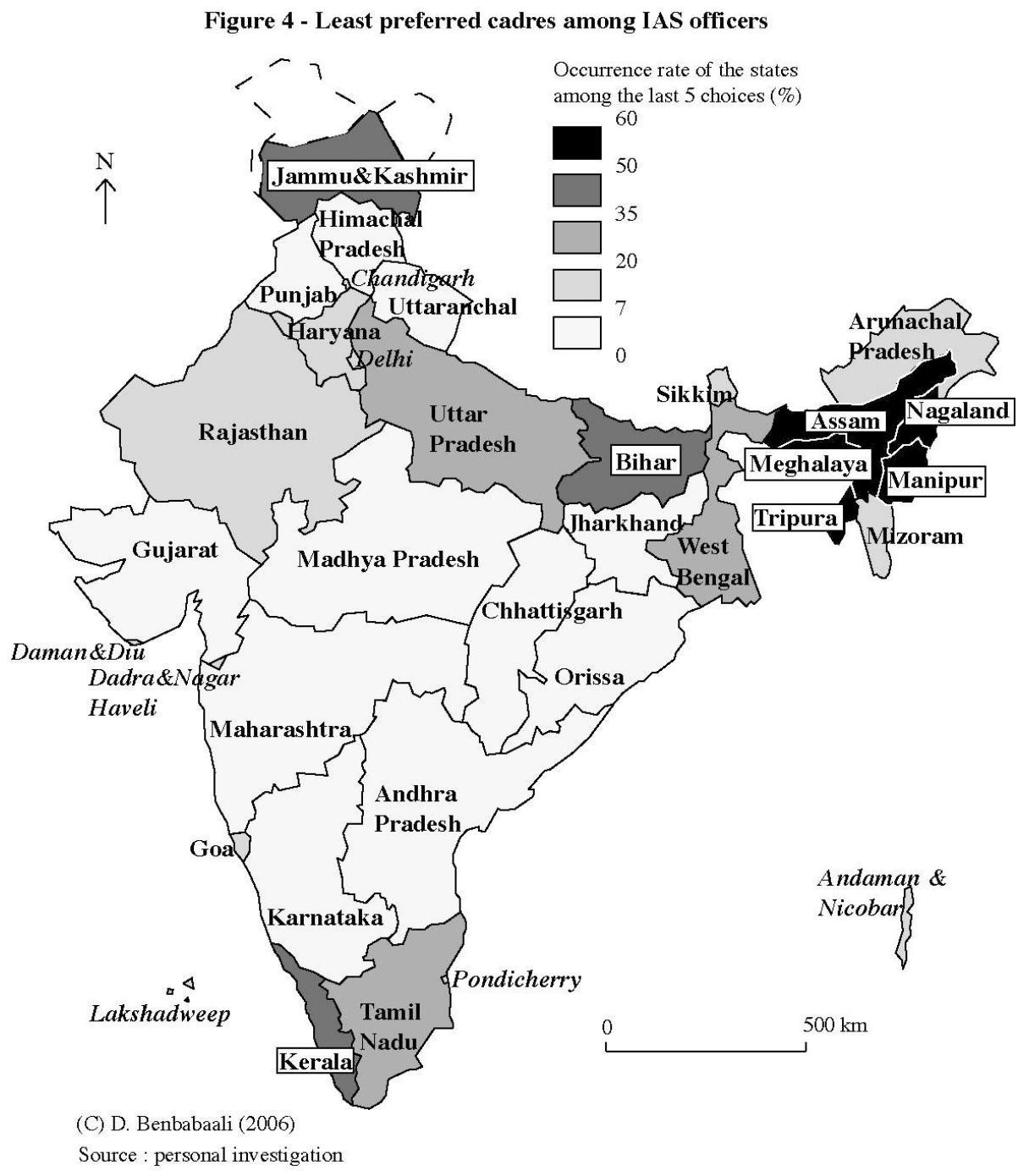

[39] Figure 4 is based on the answers of the interviewed IAS on their last five cadre choices. It appears clearly on this map that the least sought-after cadres are all peripheral states. The North-Eastern states are considered as 'bad cadres' because of their distance from the mainland, lack of accessibility, but also because of their strong ethnic identities and the political troubles created by separatist insurgents.One IAS from Andhra Pradesh, who was alloted Assam, remembers his family's reaction when they came to know about it: 'When I told my mother that I was posted in Assam, she started crying. I asked her why. She said that the only time she heard about Assam was in a Telugu movie in which the hero punishes the villain by putting him in a train to Assam'. It is also due to security problems that civil servants prefer to avoid the Kashmir cadre. Bihar is considered as a 'bad cadre' because of the collapse of governance and the chaotic administrative structure of this state (see also Appu 2005). There is a general feeling among IAS officers that Kerala, a communist-governed state for many years, does not give them much power. The population of that state, the most educated and unionised of India, in the words 
Benbabaali, Dalal (2008) 'Questioning the Role of the Indian Administrative Service in National Integration', South Asia Multidisciplinary Academic Journal, URL : http://samaj.revues.org/document 633.html. To quote a passage, use paragraph (§).

of the interviewed probationers, 'gives no more respect to IAS officers than to clerks', which is rather irritating for this elite body of the administration.

[40] Some states are deficit cadres because of the disaffection of IAS officers, especially in the North-East, where some postings remain vacant in the higher administration ${ }^{19}$. Civil servants adopt diverse strategies to avoid going to these states, ranging from marriage to political intrigues. The officers who are already engaged or married when joining the service can adopt temporary strategies to escape from their cadre. After a compulsory period spent in the field, they can ask for a deputation to the central government in Delhi. Power and patronage being concentrated in the national capital, there is a rat race among IAS officers to join important ministries (Mukherjee 1994). In fact, those appointments are monopolised by a small number of IAS officers with the right connections and good political backing ${ }^{20}$. High-level civil servants can also go abroad for a couple of years, and some of them even get prestigious postings in the UN or WTO. IAS officers thus spend a lot of time building their careers and improving their service prospects, some of them thereby neglecting their jobs in the field and the dire needs of the states deserted by the higher administration.

[41] The supporters of the integrative role of the IAS quote examples of civil servants who get acclimatised to their cadres, not bothering to move to the centre, even settling down in their adoptive state after retirement. But this occurs only in the states which have big metropolises where the living standards are good and access to medical facilities easy. It also happens with officers who amassed wealth during their career in the form of landed estates, houses and even industries (sometimes disproportionate to their known sources of income ${ }^{21}$ ). Yet, in the NorthEastern states, IAS officers cannot buy any real estate (according to a law which protects tribal lands), and they probably do not wish to do so, since most of them prefer to go back to their home state after retirement. The North-East case, where secessionist movements are still active, points out the limitations of the national integration policy through the higher civil service. Neither are the IAS officers willing to serve the local people from whom they feel alienated by a wide

\footnotetext{
19 In 2002 for example, there were 7 vacancies in Manipur-Tripura, and only 3 in Uttar Pradesh.

20 'It is only a small number of nearly 300 officers who keep hovering around Delhi out of the total membership of nearly 5,000 and who act as gate-keepers preventing their other colleagues from getting central postings' (Maheshwari 2005: 139).

21 'In both the Indian Administrative Service and the Indian Police Service there are about 15\% officers in senior age-groups who are multimillionaires' N.S. Saksena, of Indian Police (quoted in Maheshwari 2005: 151).
} 
Benbabaali, Dalal (2008) 'Questioning the Role of the Indian Administrative Service in National Integration', South Asia Multidisciplinary Academic Journal, URL : http://samaj.revues.org/document 633.html. To quote a passage, use paragraph (§).

cultural and ethnic gap, nor these populations accept to put their destiny in the hands of agents of an external power that, according to them, tries to dominate and assimilate them.

\section{Conclusion}

[42] The argument that the IAS serves to promote the unity and integrity of the Indian nation, transcending cleavages and differences which form the basis for states' identities, seems much less convincing in the contemporary situation than it might have been at Independence. The contribution of the All-India Services to cementing or safeguarding the Union cannot be reckoned as crucial, compared with the historical, political and cultural factors which make Indians feel that they belong to the same nation, whatever their differences. The efforts to make the higher civil service more representative through reservations are limited to a purely quantitative approach to national integration, and do not transcend the social, religious and ethnic cleavages that divide Indian society. How could an elite administration itself affected by casteism, communalism and regionalism offer the perspective of a collective quest for common goals? Vertical solidarity between bureaucrats and politicians seems to prevail over the horizontal solidarity of a composite body of IAS officers, who align themselves with political parties on a caste basis, or simply for opportunist motives of career advancement.

[42] Some upright IAS officers resist this trend, but they cannot alone change a system which victimises them through harassment and pressures from local politicians, frequent punitive transfers and threats to their families. To put an end to this abuse of power, the current Manmohan Singh government has decided to limit the prerogatives of Chief Ministers with regard to All-India civil servants ${ }^{22}$. But in a democratic set-up, politicians will continue to be at the helm of affairs. If they do not find political incentives in reforming public service institutions towards achieving good governance, any alternative institution, however well designed in theory, is likely to face similar pressures.

[43] That is why the abolition of the All-India Services ${ }^{23}$, which have not proved efficient in fulfilling national integration policies, does not constitute a solution in itself. It would lead to the

22 'In a big push to governance reforms, the Manmohan Singh government has finally notified the fixed tenure rule for All-India Service officers posted in the states. Now, a committee headed by the Chief Secretary has to approve any decision to transfer a bureaucrat before his minimum tenure is over', Hindustan Times, September 142006.

${ }^{23}$ See Venkataratnam, 2005. 
Benbabaali, Dalal (2008) 'Questioning the Role of the Indian Administrative Service in National Integration', South Asia Multidisciplinary Academic Journal, URL : http://samaj.revues.org/document 633.html. To quote a passage, use paragraph (§).

preeminence of the State Civil Services, which are considered to be even more parochial in outlook. Reforming the IAS is neither an easy task. Successive commissions for administrative reforms have submitted reports and recommendations over the years, without bringing any fundamental change to the institution. The IAS officers form a powerful lobby at the national level, and they will certainly resist any proposal that threatens their position, even when the objective is to make them more accountable to the public, especially by removing the constitutional protection given to them. The officers who fail in their mission of public service, the openly corrupt, the partisan, still enjoy the security of tenure guaranteed to them by the Constitution, which makes their dismissal very difficult.

[44] The elitist character of the higher civil service was supposed to ensure the probity of its members and to put them above special interests. But today some Indian commentators admit that 'we have been expecting too much from the bureaucracy because it was elitist. Elitism is not synonymous with neutralism or with fair play' (Venkataratnam 2005). The partisanship of highlevel civil servants goes against their mission of national integration. If nothing is done to increase the effectiveness of the IAS as a binding force of the country, and if, instead of contributing to national unity, its members deepen even more the existing social cleavages by their partiality, then the whole institution loses its raison d'être. 
Benbabaali, Dalal (2008) 'Questioning the Role of the Indian Administrative Service in National Integration', South Asia Multidisciplinary Academic Journal, URL : http://samaj.revues.org/document 633.html. To quote a passage, use paragraph (§).

\section{References}

Appu, P.S. (2005) 'The All-India Services. Decline, Debasement and Destruction', Economic and Political Weekly, 40(9), pp. 826-832.

Arora, Balveer; Radin, Beryl (2000) The Changing Role of the All-India Services. An Assessment and Agenda for Future Research on Federalism and the All-India Services, New Delhi: Centre for the Advanced Study of India.

Banik, Dan (2001) 'The Transfer Raj: Indian Civil Servants on the Move', The European Journal of Development Research', 13(1), pp. 106-134.

Barik, R.K. (2005) 'Decline of All-India Services', Economic and Political Weekly, 40(17), pp. 1790-1791.

Bhaumik, Subir (2004) 'Ethnicity, Ideology and Religion: Separatist Movements in India's Northeast', in Satu P. Limaye (ed.) Religious Radicalism and Security in South Asia, Hawai: AsiaPacific Center for Security Studies, pp. 219-244.

Bourdieu, Pierre (1989) La noblesse d'Etat. Grandes Ecoles et esprit de corps, Paris: Les Editions de Minuit.

Chakrabarty, Bidyut (2006) 'Jawaharlal Nehru and Administrative Reconstruction in India: a mere imitation of the past or a creative initiative?', South Asia: Journal of South Asian Studies, 29(1), pp. 83-99. Faber.

Chatterjee, Upamanyu (1988) English August. An Indian Story, London: Faber and

Das, S.K. (2005) 'Reforms and the Indian Administrative Service', in Jos Mooij (ed.) The Politics of Economic Reforms in India, Delhi: Sage, pp. 171-196.

Dolan, Julie; Rosenbloom David H. (eds.) (2003) Representative Bureaucracy. Classic Readings and Continuing Controversies, New York: M.E. Sharpe.

D’Souza, J.B. (2002) 'Gujarat: a Civil Service failure. How can credibility be restored?', Economic and Political Weekly, 37(34), pp. 3492-3493.

Dwivedi, O.P.; Mishra D.S. (2005) 'A Good Governance Model for India: search from within', Indian Journal of Public Administration, 51(4), pp. 719-758.

Evans, Peter (1992) 'The State as Problem and Solution: Predation, Embedded Autonomy, and Structural Change', in Stephan Haggard \& Robert Kaufman (eds.) The Politics of Economic Adjustment. International Constraints, Distributive Conflicts, and the State, New Jersey: Princeton University Press, pp. 139-181.

Forster, E.M. (2005) A Passage to India, New Delhi: Peacock Books.

Government of India (1980) Report of the Backward Classes Commission, New Delhi.

Government of India, Central Vigilance Commission (2001) The Indian Administrative Service: a study of the current state of punitive and preventive vigilance mechanisms, New Delhi: Satarkata Bhawan.

Goyal, Santosh (1989) 'Social Background of Officers in the Indian Administrative Service', in Francine R. Frankel \& M.S.A. Rao (eds.) Dominance and State Power in Modern India, Delhi: Oxford University Press, pp. 425-433. 
Benbabaali, Dalal (2008) 'Questioning the Role of the Indian Administrative Service in National Integration', South Asia Multidisciplinary Academic Journal, URL : http://samaj.revues.org/document 633.html. To quote a passage, use paragraph (§).

Calcutta: Papyrus.

Gupta, Shaibal K. (1996) A Foot in the Door of the Indian Civil Service, 1859-1943,

Kingsley, J.Donald (1944) Representative Bureaucracy: an Interpretation of the British Civil Service, Yellow Springs, Ohio: Antioch Press.

Maheshwari, S.R. (2005) Public Administration in India. The Higher Civil Service, Delhi: Oxford University Press.

Mason, Philip (1985) The Men who ruled India, New Delhi: Rupa.

Mehta, Vinod (ed.) (2000) Reforming Administration in India, Delhi: ICSSR, Har-Anand Publications.

Mishra, D.S. (2006) 'Administering a District in India: Reviewing Collector's Institution', Indian Journal of Public Administration, 52(1), pp. 45-63.

Mosher, Frederick C. (1968) Democracy and the Public Service, New York: Oxford University Press.

Mukherjee, B.C. (1994) Administration in Changing India, Delhi: Blaze Publishers.

Potter, David (1996) India's Political Administrators. From ICS to IAS, Delhi: Oxford University Press.

Puri, Mukesh (2004) 'Profile of Entrants to Civil Services, 1997-2004', The Administrator, XLVII, pp. 132-145.

Rudolph, Lloyd I.; Rudolph Susanne Hoeber (1987) In Pursuit of Lakshmi. The Political Economy of the Indian State, Chicago: University of Chicago Press.

Singh, Balwant (1964) An Untouchable in the I.A.S., Saharanpur: Prem Printing Press.

Subramaniam, V. (1971) Social Background of India's Administrators. A Socio-Economic Study of the Higher Civil Services of India, New Delhi, Ministry of Information and Broadcasting.

Venkataratnam (2005) 'All-India Services: time to disband', Economic and Political Weekly, 40(17), p. 1791.

Wade, Robert (1985) 'The Market for Public Office: Why the Indian State is not better at Development', World Development, 13(4), pp. 467-497. 